\title{
Preservação do patrimônio genético original da humanidade
}

\author{
Juliana Ramos Fernandes ${ }^{1}$
}

\begin{abstract}
Resumo
Diante da acelerada evolução dos métodos científicos, principalmente em relação aos procedimentos da moderna biotecnologia, cabe ao Direito, como mecanismo regulador de condutas, acompanhar as evoluções humanas e sócio-culturais tutelando bens jurídicos, com o intuito de evitar danos irrersíveis para a humanidade. A clonagem ${ }^{2}$ surge como um marco do desenvolvimento de técnicas de manipulação celular e genética e, diante de todas as conseqüências que pode acarretar há a necessidade de ser tutelada penalmente, considerando-se pontos essenciais como à dignidade da pessoa humana e a importância fundamental da preservação do patrimônio genético original da humanidade.
\end{abstract}

Palavras-Chave: Biotecnologia; Clonagem; Dignidade da pessoa humana; Patrimônio genético da humanidade; Bem jurídico; Indivíduo; Direitos fundamentais.

\section{Introdução}

A Técnica de clonagem vem como marco histórico para a pesquisa científica e tecnológica. No entanto, junto à tamanha evolução surge a necessidade da tutela jurídica, evitando-se desta forma a violação de direitos constitucionais fundamentais, alicerces de todo um Sistema Jurídico, os quais representam um Estado Social Democrático de Direito.

O princípio da dignidade da pessoa humana ${ }^{3}$, pedra angular da Constituição Federal Brasileira e, outros direitos constitucionais fundamentais como o direito à vida, à integridade corporal, à intimidade, à honra; vêm como limitadores do direito constitucional de liberdade científica e tecnológica.

1 Pós-graduanda pela Universidade Estadual de Londrina (UEL) no curso de Especialização em Direito e Processo Penal.

2 “... é um processo de reprodução assexuada, produzida artificialmente, baseada em um único patrimônio genético, com ou sem utilização de técnicas de engenharia genética (art. 3o, VIII, Lei 11.105/2005). Clonar, enquanto mecanismo de reprodução assexuada (v.g. técnica de transferência nuclear celular) significa criar um ser humano com o mesmo código genético de outro já existente, vivo ou morto. Trata-se, portanto, de duplicar o material genético de uma célula ou organismo, sem alterá-lo" (PRADO, 2005, p. 585).

3 A previsão da dignidade da pessoa humana como valor fundante do sistema de direitos fundamentais (art. 10 , III, CF/88) implica o reconhecimento do homem como pessoa e não apenas como cidadão, outorgandoIhe um núcleo de prerrogativas que o Estado não pode deixar de reconhecer, como uma verdadeira esfera de ação dos indivíduos que delimita o poder estatal (CARVALHO, 2005, p. 388). 
São inúmeras as conseqüências trazidas pela clonagem humana, podendo trazer resultados nefastos para a humanidade. Somente a perspectiva de se reproduzir sereshumanos, violando-se o direito à identidade e muitos outros já justifica plenamente a tutela penal da inalterabilidade do patrimônio genético original da humanidade.

Torna-se extremamente necessário restringir o direito à liberdade científica e tecnológica para o bem da humanidade preservando-se assim o patrimônio genético original $^{4}$.

\section{Regulamentação legal}

A Constituição Federal Brasileira menciona no artigo 225 que todos têm direito ao meio ambiente ecologicamente equilibrado, bem de uso comum do povo e essencial à sadia qualidade de vida, impondo-se ao Poder Público e à coletividade o dever de defendê-lo e de preservá-lo para as presentes e futuras gerações.

Para assegurar a efetividade desse direito, dispõe que incumbe ao Poder Público preservar a diversidade e a integridade do patrimônio genético do país, fiscalizar as entidades dedicadas à pesquisa e à manipulação de material genético (artigo 225, § 1은 II), além de controlar a produção, comercialização e emprego de técnicas, métodos e substâncias que comportem risco a vida, a qualidade de vida e o ambiente (art. 225, §, 1으, $\mathrm{V})$.

Mostra-se assim que a Carta Constitucional disciplinou o patrimônio genético do ponto de vista estritamente ambiental, protegendo a integridade e a diversidade biológicas dos ecossistemas existentes no país, sem mencionar à intangibilidade do patrimônio genético da humanidade ${ }^{5}$ (MALUF, 2002, p. 15).

4 Por patrimônio genético, entende-se o universo de componentes físicos, psíquicos e culturais que permanecem constantes, embora com mutações naturais ao longo das gerações, e que em conjugação com fatores ambientais e num permanente processo de interação passam a constituir a própria identidade da raça humana, que por isso tem o direito de guardá-lo, defendê-lo e transmiti-lo. A respeito observa-se que a intangibilidade do patrimônio genético da humanidade é o que assegura a própria sobrevivência da espécie.

5 Nesse sentido, assinala-se com acerto que "a Constituição da República preserva a diversidade e integridade do patrimônio genético do País, porém não se trata de capítulo voltado especificamente ao ser humano, seja no sentido individual ou coletivo, mas sim diz respeito ao meio ambiente. Em razão disso, há que se reconhecer que a legislação pátria vigente sobre o genoma humano surge a partir da preocupação com o meio ambiente e não com o homem, de maneira direta" (DIEDRICH, 2001, p. 227). Também criticam a omissão da Constituição no tocante à tutela do patrimônio genético humano (MALUF, 2002, p. 15) e (SANT'ANNA, 2001, p. 113-114). 
Porém esta concepção de proteção do patrimônio genético da humanidade encontra-se ínsita à própria constituição em seu quadro axiológico e a concepção de Estado de Direito Democrático adotada pelo texto constitucional, o qual tem por princípio basilar a dignidade da pessoa humana, inviabilizando desta forma qualquer conduta que implique a instrumentalização do ser humano.

Inicialmente o artigo $225, \S 1$ 으 II e V da Constituição Federal foi regulamentado pela lei 8974/1995, a qual trazia normas para o uso das técnicas de engenharia genética e para a liberação, no meio ambiente, de organismos geneticamente modificados (OGM), além do que autorizava o Poder Executivo a criar, no âmbito da Presidência da República, a Comissão Técnica Nacional de Biossegurança (CTNBio). ${ }^{6}$ Assim, foi o primeiro diploma legislativo especialmente destinado a regular a proteção do patrimônio genético no país.

Devido à evolução sobre a matéria e inúmeros fatos inovadores fez-se necessário um novo texto legislativo, sendo a Lei 8974/95 substituída pela Lei 11.105 de 24.03.2005, conhecida como "Lei de Biossegurança", a qual trouxe inovações em matéria de cultivo e comercialização de organismos geneticamente modificados (OGM), e ainda a regulamentação da experimentação com embriões humanos e a liberação das pesquisas com células-tronco de origem embrionária.

No artigo 26 a mencionada Lei de Biossegurança colmatou uma lacuna da antiga lei 8974/1995, tipificando a conduta de "realizar clonagem humana"7 . O bem jurídico protegido vem a ser a identidade e a irrepetibilidade do ser humano, de cada indivíduo. Indiretamente, tutela-se também a inalterabilidade do patrimônio genético da humanidade. Como objeto material têm-se os gametas e embriões (CARVALHO, 2005, p. 403).

6 É oportuno registrar que entre inúmeros defeitos de que padecia a antiga Lei, encontram-se não só aqueles relacionados ao descompasso verificado entre o texto legal e o vertiginoso progresso tecnológico relacionado às manipulações genéticas, mas também, e, sobretudo, as flagrantes violações aos princípios penais de garantia. Nesse sentido, o que mais saltava à vista era o fato de que, ao proceder à tipificação das condutas penalmente relevantes na anterior Lei 8974/1995, o legislador não respeitava alguns princípios penais básicos, como o da legalidade penal e o da taxatividade ou determinação, que impõem a descrição precisa da conduta humana prescrita pela norma. Ao contrário: tão somente enunciava, em termos gerais, a atividade violadora do bem jurídico, mas não a conduta humana que a realizava. Por favor, senhor Ministro da Justiça.

7 "A clonagem definida grosso modo como a duplicação de um material genético determinado, pode ser abordada segundo dois aspectos: como prática de engenharia genética molecular ou não molecular. No primeiro caso, tem-se a duplicação de genes, provenientes das moléculas de DNA das células humanas, através de bactérias ou leveduras, de forma a se obter genes idênticos ao clonado. Já a clonagem nãomolecular toma por base a célula germinal feminina e o pré-embrião em suas primeiras etapas de desenvolvimento para a criação de seres geneticamente idênticos - isto é, portadores do mesmo genótipo" (CARVALHO, 2005, p. 403). 
A lei estabelece duas hipóteses de clonagem humana, levando em consideração as finalidades a que se destinam, quais seja, uma para fins reprodutivos - clonagem com a finalidade e obtenção de um indivíduo (art. 3으, IX) - e outra com escopo terapêutico clonagem com a finalidade de produção de células-tronco embrionárias para utilização terapêutica (art. 3으, X).

\section{Nova lei de biossegurança}

A Nova lei de Biossegurança tutelou o delito da clonagem de forma extremamente amena, diante das conseqüências que a referida conduta pode vir a produzir, trazendo graves riscos aos direitos fundamentais e ao futuro da espécie humana.

A pena de dois a cinco anos de reclusão e multa mostra-se ínfima, não amedrontando seus autores perante as enormes perspectivas de lucro com sua pratica. Diante da possibilidade de submeter-se a tal pena e, em contrapartida, poder clonar sereshumanos perfeitos, a pena prevista pelo artigo 26 da lei 11.105/2005 pode ser encarada mesmo como um incentivo a essa atividade não lucrativa.

Nesse aspecto, infelizmente a lei não cumpriu o seu papel de prevenção e muito menos o de retribuição.

\section{Benefícios alegados}

Ao tutelar penalmente a identidade e a irrepetibilidade do ser humano, a Lei de Biossegurança não faz distinção entre a clonagem para fins reprodutivos e a clonagem para fins terapêuticos, sancionando ambas da mesma forma.

\subsection{Clonagem terapêutica}

A clonagem terapêutica é a clonagem com a finalidade de produção de célulastronco embrionárias para utilização terapêutica (art. $3^{\circ}$ X, da Lei de 11.105/2005).

Apesar de a clonagem terapêutica implicar a perda de muitos embriões humanos, os ganhos obtidos com a redução da doença e do sofrimento humano são pelo menos comparáveis, e provavelmente maiores, aos obtidos com a reprodução sexual normal e com a fertilização in vitro. 
Muitas doenças são causadas pela falta ou destruição de células específicas, as quais podem (teoricamente) ser produzidas a partir de células tronco humanas. Estas podem se derivadas de embriões (sejam ou não clonados), de fetos ou de organismos adultos.

Até pouco tempo atrás não se tinha acesso às células- tronco humanas, as células básicas que podem transformar-se em diferentes tipos de células especializadas, e que não podem se desenvolver em laboratório, a não ser em alguns casos excepcionais.

Atualmente com o avanço científico-tecnológico havido tanto na biologia como na medicina pode-se desenvolver células-tronco embrionárias, diferenciá-las e fazer com que se transformem nas células especializadas necessárias para tratamento de determinada doença.

A clonagem terapêutica tem hoje poucas aplicações, mas há muitas aplicações potenciais, e é grande a esperança do que ela poderá fazer.

Doenças como Parkinson, Alzheimer, diabete (tipo 1), insuficiência cardíaca depois do infarto do miocárdio, insuficiência do fígado, osteoartrose, insuficiência da medula óssea, poderão ser tratadas com a clonagem terapêutica.

\subsection{Clonagem reprodutiva}

A clonagem para fins reprodutivos "clonagem com a finalidade de obtenção de um indivíduo" (art. 3, IX, da LB), é vista por alguns como uma solução para a infertilidade de determinados casais e, ainda, como método de reprodução de seres humanos perfeitos.

Dentre os que defendem a clonagem reprodutiva, o professor Renato Sabbatini (1999), considera que em termos de preservação da identidade pessoal própria de cada ser, como qualquer casal que teve filhos gêmeos sabe, os genes não são tudo. $O$ efeito do desenvolvimento pós-natal, do aprendizado, do ambiente, e até de eventos aleatórios, são fundamentais para formar uma parte considerável da personalidade e maneira de ser. E essa parte da vida não pode ser clonada. Portanto, na opinião desse autor, é outro mito e absurdo o temor de que se vai poder criar populações inteiras de "super-homens" ou "super-mulheres"... A vida é muito mais complexa do que esses exercícios pueris de ficção científica. Depois de alguns anos, esses seres clonados seriam bastante diferentes uns dos outros, acabando com o plano de seus pretensos criadores. 
Para Renato Sabbatini (1999) não se trata a clonagem de um atentado ao princípio do respeito às pessoas, pois a própria natureza já realiza milhares de "experimentos" semelhantes à clonagem todos os anos, e ninguém acha nada demais. Revela inclusive que são os gêmeos univitelinos, "clones" perfeitos um do outro. "Todo mundo acha até bonitinho, encantador; vestem os filhos da mesma maneira. Qual é o problema ético de se ter dois gêmeos dessincronizados em idade? Não vejo nenhum" (SABBATINI, 1999).

O professor Robert Wachbroit (1999), do Institute for Philosofy and Public Policy, dos Estados Unidos, revela que muito do temor em relação à figura do clone humano está relacionado a um pseudo determinismo genético, pelo qual o clone não seria um indivíduo, mas uma mera "cópia carbono" de alguma outra pessoa - um verdadeiro autômato como aqueles que aparecem nos filmes de fiç̧ão científica. Afirma que, no entanto, não é verdade que assim possa vir a ser. O consenso científico - mormente com as revelações a partir do desenvolvimento do mapeamento do Genoma Humano - é no sentido de que os biólogos tornaram-se mais cientes das maneiras inumeráveis pelas quais o meio ambiente afeta o ser humano em sua expressão biológica como um todo. A contribuição genética desde os traços físicos os mais simples, tais como a altura e a cor do cabelo, é mediada significativamente por fatores ambientais (e possivelmente por eventos estocásticos também). E, inclusive a contribuição genética relativa aos traços que se avalia como mais profundamente determinados geneticamente, como a inteligência e a sensibilidade, tendem a ser vistos, ainda que pelos investigadores genéticos mais entusiásticos como limitados e indiretamente influenciados pelo ambiente que rodeia o ser.

\section{Dos riscos alegados}

\subsection{Clonagem terapêutica}

A clonagem terapêutica envolve a criação de embriões humanos exclusivamente para produzir células-tronco. Utilizando-se destes embriões meramente como um meio, sempre presente o conceito do "imperativo categórico" de Emmanuel Kant, segundo o qual nunca devemos tratar os outros apenas como um meio, mas sempre como um fim.

Outro argumento é que a clonagem terapêutica pode contribuir incidentalmente para que a clonagem reprodutiva seja feita. 
E finalmente, importante ressaltar que atualmente a clonagem terapêutica é desnecessária, considerando que há outros tipos de células-tronco disponíveis.

\subsection{Clonagem reprodutiva}

O processo de clonagem reprodutiva, com a finalidade de dar a vida a uma cópia idêntica de um outro ser, ainda é extremamente ineficiente. De 276 (duzentos e setenta e seis) embriões manipulados, somente 29 sobreviveram para serem implantados em ovelhas, e, destes, somente um vingou, dando origem à universalmente conhecida Dolly.

Não há como garantir a integridade dos genes da célula somática, e consequentemente, dos genes do clone. Corre-se o risco de gerar "monstros", ou ainda, clones aparentemente normais, no entanto, com alterações em seus genes que só se manifestarão a longo prazo.

Ao procriarem os clones poderão transmitir alterações genéticas pela população humana que podem vir a se manifestar somente depois de várias gerações, quando já estarão presente em um número significativo de pessoas, alterando o patrimônio genético humano de forma irreversível.

A clonagem é ainda uma técnica pouco compreendida e, com enormes riscos, considerando que na maior parte dos casos os embriões clonados são abortados ou dão origem a fetos deformados, que morrem nos primeiros dias de vida.

Apresentam ainda sérios problemas como o envelhecimento precoce ou encolhimento dos telômeros (estruturas cromossômicas que se desgastam a medida que a célula se divide e envelhece).

O quadro abaixo mostra os principais problemas que poderiam ocorrer como a clonagem humana: 


\section{OS RISCOS DA CLONAGEM}

Baseado nas experiencias com animais, estas seriam as probabilidades e consequeencias de se clonar um ser humano hoje, segundo especialistas

(1) Dos 100 primeiros embrides clonados implantados em males de aluguel, quase todos seráo abortados espontaneamente por causa de anomalias físicas ou genéticas

Entre as poucas mulheres que engravidarem, a maioria desenvolverá placentas grandes demais e terá acúmulo de gordura no figado. As maes tamberm costumam inchar, - que pode acarretar problemas cardíacos, respiratorios e até rompimento da mus. culatura do abdome
(3) Tres ou quatro do cem fetos poderao sobreviver ao nascimento. A maioria será enorme, com até 6,5 quilos, e morrerá nos primeiros dias de vida por problemas cardiacos ou circulatórios, pulmóes subdesenvolvidos, diabete ou deficiencias imunológicas

\section{(4) Se um dos bebes sobreviver,} ele terá a marca característica da maioria dos animais clonados: um enorme umbigo, resultante de um cordâo umbilical aumentado que, inexplicavelmente, se desenvolve na gestaçâo dos clones

Antrisdo

\section{Quadro 1}

Fonte: Jornal Estado de São Paulo.

Além de enfrentarmos problemas genéticos, a clonagem reprodutiva viola conceitos éticos, colidindo com princípios como o da dignidade da pessoa humana, da identidade pessoal do individuo. Conceitos estes consolidados no Ordenamento Jurídico após anos de luta contra o Autoritarismo.

Dentro de um Estado Democrático de Direito é inadmissível retirar das pessoas o direito à identidade. Em um ordenamento jurídico fundado na dignidade da pessoa humana ${ }^{8}$ torna-se inaceitável que o ser humano perca seu livre arbítrio e sua autodeterminação desde seu nascimento. "Com efeito, o ser humano encerra a alteridade, individualidade,

\footnotetext{
8 "É, pois, um atributo ontológico do homem como ser integrante da espécie humana - vale em si e por si mesmo" (PRADO, 2005, p. 145).
} 
identidade, não podendo ser enclausurado, acorrentado, desde sua origem, sem perder seu estatuto no contexto da humanidade" (PRADO, 2005, p. 587).

A clonagem pode apresentar riscos irreversíveis para a humanidade como: o risco de destruição do direito à identidade genética; risco da clonagem do homem ótimo, do super-homem (programação ou reprodução totalitária de seres humanos em série); risco de implicações imprevisíveis em sua totalidade, visto que a diversidade genética é basilar para a sobrevivência de qualquer espécie; risco do predomínio de uma determinada geração, entre outros 9 .

Também contra o processo de clonagem reprodutiva o professor Paulo Otero (1999), considera que, em função da infungibilidade, indivisibilidade e irrepetibilidade da pessoa humana, garantida pelas Constituições, através do reconhecimento do direito fundamental à identidade pessoal na sua dimensão absoluta, resulta uma principal conseqüência: a total e absoluta proibição da clonagem humana, por se tratar de processo mediante o qual se consegue a criação de seres humanos rigorosamente iguais, "verdadeiro mecanismo de produção em 'fotocópia' de um mesmo ser" (OTERO, 1999).

$\mathrm{O}$ desrespeito à pessoa do clone residiria em se negar a esta pessoa o direito a possuir um patrimônio genético próprio e único, pois que esta pessoa geneticamente nada mais é que uma cópia biológica, implicando em profundo atentado contra seus direitos fundamentais inalienáveis, entre eles "o direito de ser um ser único".

Não somente por essa razão, pois o autor também se reporta à questão da identidade pessoal relativa - a historicidade pessoal, que envolve o direito de cada ser humano conhecer a forma como foi gerado ou, mais amplamente, o direito a conhecer o seu

9 Recomendações do Conselho da Europa (934,1982; 1.046, 1986; 13,1990). A respeito da viabilidade técnica da clonagem, pontifica-se que "parece certo que não é factível criar seres completamente idênticos a outros já existentes, primeiramente do ponto de vista biológico, pois o DNA mitocondrial não é sempre idêntico, em razão da técnica utilizada (assim ocorre quando se transfere um núcleo a um óvulo enucleado), existem influências entre citoplasma e núcleo, assim como outras do meio uterino (hormonais nos primeiros dias de gestação), sem olvidar a possibilidade de mutações genéticas espontâneas. Em segundo lugar é certo que o ser humano, sua personalidade, é fruto também de fatores ambientais de espaço (culturais, familiares, sociais) e de tempo ( a sucessão temporal-geracional dos seres vivos em geral e do ser humano em particular, que também apresenta variações culturais). Ou seja, que se o princípio da individualização do ser humano é o resultado de sua singularidade biológica e pessoal (fruto do desenvolvimento, da educação e de outros fatores mencionados), só a primeira poderia ver-se afetada pela clonagem, isto é, pela origem clônica desse indivíduo. A esse respeito, representam uma prova tranqüilizadora os gêmeos monozigóticos, os quais possuindo uma dotação genética idêntica e um ambiente temporal e, geralmente, espacial semelhantes, não desenvolvem uma personalidade idêntica" (CASABONA, 2004, p. 86-87). 
patrimônio genético e o concreto direito de cada pessoa em conhecer a identidade de seus progenitores. Mais que isso, argumenta o autor, a historicidade pessoal, vista como expressão do direito à identidade pessoal envolve a proibição de privação deliberada de família, proibição esta resultante da tutela constitucional conferida à maternidade e à paternidade que, além de valores sociais eminentes que o Estado tem que garantir, são fatores de efetivação do direito ao desenvolvimento integral da personalidade e instrumentos garantísticos do próprio valor de família como elemento natural e fundamental da sociedade.

Junges (1999) argumenta ainda que, "muito embora se possa considerar que a identidade genética (genótipo) não implica necessariamente na identidade pessoal (fenótipa e psíquico-social), pelo fato desta última depender muito mais do ambiente que é impossível reproduzir para um clone, também fica muito difícil desabrochar para a autonomia vivendo à sombra de quem se é cópia". E complementa que a história pessoal de cada um determina, em muito, a própria identidade do ser. E, exatamente por isso, ainda que exista uma identidade genética entre clone e o clonado, jamais poderão ser idênticos quanto à sua realidade psíquico-espiritual. Isto porque é impossível reproduzir em outro a identidade pessoal de alguém, o que leva a um outro problema relativo ao respeito à pessoa: "O fato de ser um clone será um handicap que poderá atrapalhar e dificultar a constituição da identidade pessoal" (JUNGES, 1999). Considera que todo ser humano tem o direito de ser único e irrepetível, diferente de todos os demais. O desrespeito a essa condição estaria configurado como grave violação ao princípio da dignidade humana, manifestando na tendência atual da sociedade em nivelar e uniformizar as pessoas em todos os sentidos.

\section{Conclusão}

Sem contrapor-se ao direito de liberdade à pesquisa científica, previsto constitucionalmente, a lei de Biossegurança acertadamente sancionou a clonagem.

No entanto, olvidou-se de diferenciar clonagem terapêutica de clonagem humana, sancionando ambas da mesma forma, a despeito de suas distintas finalidades.

Apesar de a clonagem terapêutica transformar os embriões em meros meios para a produção de células-tronco, podendo ainda contribuir com a clonagem reprodutiva; o 
individuo que a pratica, em regra, esta imbuído com intenções de cura de diversas doenças e contribuição para a pesquisa científica.

Assim o dolo daquele que pratica a clonagem terapêutica é diverso daquele que pratica a clonagem reprodutiva.

$\mathrm{O}$ individuo que pratica a clonagem reprodutiva a rigor representa uma vertente da ciência preocupada meramente em satisfazer desejos frívolos dos seres-humanos, desprezando princípios já arraigados no Ordenamento Jurídico e, aviltando as conseqüências nefastas que esta pratica pode causar.

Assim a "Lei de Biossegurança" mostrou-se totalmente desarmônica ao tipificar clonagem sem diferenciar a clonagem terapêutica da reprodutiva.

E ainda, acabou por menosprezar o referido delito, delimitando-lhe uma sanção irrisória comparada as conseqüências calamitosas que pode vir a causar, principalmente quando se tratar de clonagem reprodutiva.

A clonagem, em essencial a reprodutiva, viola conceitos basilares do Ordenamento Jurídico e deve ser punida de forma severa. O Estado Social Democrático de Direito de forma alguma deve comportar medidas que violem seus conceitos e princípios fundamentais.

Cabe ao Direito Penal tutelar de forma rígida as condutas que possam vir a lesionar a dignidade da pessoa humana. Infelizmente o Ordenamento Jurídico Brasileiro ainda não alcançou a forma ideal de fazê-la e, em meio às desastrosas tentativas, direitos essências ao ser humano são transgredidos impunemente.

Deve assim o direito adequar-se à evolução da ciência, intervindo de forma eficaz na defesa dos bens jurídicos imprescindíveis à coexistência pacifica dos homens.

\section{Referências}

BASTOS, Celso Ribeiro. Comentários à Constituição do Brasil: promulgada em 5 de outubro de 1988. Celso Ribeiro Bastos, Ives Gandra Martins. São Paulo: Saraiva, 1988-1989.

BONAVIDES, Paulo. Curso de direito constitucional. 9. ed. rev. atual. amp. São Paulo: Malheiros Editores, 2000.

CARRERA, Francisco. Lei dos crimes ambientais. Rio de Janeiro: Esplanada, 1999. 
CASABONA, Carlos Maria Romeo. A clonagem humana: pressupostos para uma intervenção jurídico-penal. CP - RABPCP, 0, 2004.

CARVALHO, Gisele Mendes de. Reflexões sobre a clonagem terapêutica e a proteção penal do embrião humano. Revista dos Tribunais, v. 94, n. 842, 2005.

CRETELLA JÚNIOR, José. Comentários à Constituição brasileira de 1988. v. 2. Rio de Janeiro: Forense Universitária, 1991.

DELMANTO, Celso. Código penal comentado. 3. ed. atual. e ampl. por Roberto Delmanto. Rio de Janeiro: Renovar, 1991.

DIEDRICH, Gislayne Fátima. Genoma humano: Direito Internacional e legislação brasileira. In: SANTOS, Maria Celeste Cordeiros Leite dos (Coord.). Biodireito: ciência da vida, os novos desafios. São Paulo: RT, 2001.

DI PIETRO, M. S. Z. Direito administrativo. 13. ed. São Paulo: Atlas, 2001.

DOTTI, René Ariel. Os atentados ao meio ambiente: responsabilidade e sanções penais. Revista Brasileira de Ciências Criminais, São Paulo, v. 2, n. 7. jul./set. 1994.

FERREIRA, Aurélio Buarque de Holanda. Novo dicionário da língua portuguesa. 2. ed. rev. e aum. Rio de Janeiro: Nova Fronteira, 1986.

FERREIRA FILHO, Manoel Gonçalves. Comentários à Constituição brasileira de 1988. São Paulo: Saraiva, 1990.

FRAGOSO, Heleno Cláudio. Lições de direito penal, parte especial: edição universitária. vol. I - arts. 121 a 212 do CP. 1. ed. rev. e atual. por Fernando Fragoso. Rio de Janeiro: Forense, 1989.

GOMES, Luiz Flávio; BIANCHINI, Alice. A distorcionante instrumentalização do direito penal. In: O DIREITO penal na era da globalização: hipertrofia irracional (caos normativo), instrumentalização distorcionante... São Paulo: Revista dos Tribunais, 2002.

. Polícia do meio ambiente. Revista Forense, Rio de Janeiro, v. 88, n. 317, p. 179-187, jan./mar. 1992.

. Proteção penal do meio ambiente. Revista dos Tribunais. ano 80. nov. 1991. p. 390393. vol. 673. São Paulo, Revista dos Tribunais.

JESUS, Damásio E. de. Código penal anotado. 2 ed. ampl. e atual. São Paulo: Saraiva, 1991. 
JUNGES, José Roque. Bioéica prespectivas e desafios. São Leopoldo: UNISINOS, 1999.

MALUF, Edison. Manipulação genética e o Direito Penal. São Paulo: Juarez de Oliveira, 2002.

MAZZILLI, H. N. A defesa dos interesses difusos em juízo: meio ambiente, consumidor e outros interesses difusos e coletivos. 5. ed. rev. amp. e atual. São Paulo, Revista dos Tribunais, 1993.

MEIRELLES, Hely Lopes. Direito administrativo brasileiro. 21. ed. atualizada por Eurico de Andrade Azevedo, Delcio Balestero Aleixo, José Emmanuel Burle Filho. São Paulo: Malheiros Editores, 1996.

MILARÉ, É. Direito do ambiente: doutrina, prática, jurisprudência, glossário. 2. ed. rev. atual. ampl. São Paulo: Revista dos Tribunais, 2001.

. A nova tutela penal do ambiente. Revista de Direito Ambiental, São Paulo, v. 4, n. 16, p. 89-134, out./dez. 1999.

MORAES, Alexandre. Direito Constitucional. 9. ed. atual. São Paulo: Atlas, 2001.

OLIVEIRA, A. R. C. de; MIRANDA, M. P. de S.; LOURES, S. L. Considerações acerca da nova Lei de Crimes Ambientais. Jus navigandi, Teresina, v. 3, n. 27, dez. 1998. Disponível em: <http://www1.jus. com.br/doutrina/texto.asp?id=1705>. Acesso em: 14 jul. 2005.

OTERO, Paulo.Personalidade e identidade pessoal e genética do ser humano: um perfil constitucional da Bioética. Coimbra: Almedina,1999.

PIERANGELI, José Henrique. Códigos penais do Brasil: evolução histórica. 2. ed. São Paulo: Revista dos Tribunais, 2001.

PRADO, A. R. M. Proteção penal do meio ambiente: fundamentos. São Paulo: Atlas, 2000.

PRADO, Luiz Regis. Comentários ao código penal: doutrina, jurisprudência selecionada, leitura indicada. 2. ed. rev. e atual. São Paulo: Revista dos Tribunais, 2003.

PRADO, Luiz Regis. Direito Penal do Ambiente. São Paulo: Revista dos Tribunais, 2005. . Curso de direito penal brasileiro, volume 1: parte especial: arts. 10 a 120. 3. ed. rev., atual. e ampl. São Paulo: Revista dos Tribunais, 2002. 
. Crimes contra o ambiente: anotações à Lei 9.605, de 12 de fevereiro de 1998: doutrina, jurisprudência, legislação. 2. ed. rev. atual. e ampl. São Paulo: Revista dos Tribunais, 2001.

. Do deôntico ao razoável: ensaio de lógica jurídica. Revista de Ciências Jurídicas, Maringá, v. 3, n. 1, p. 23-40, 1999.

. Bem jurídico-penal e Constituição. São Paulo: Editora Revista dos Tribunais, 1997. p. $40-41$. 1992.

. Direito penal ambiental: problemas fundamentais. São Paulo: Revista dos Tribunais, . A tutela constitucional do ambiente no Brasil. Revista dos Tribunais, São Paulo, v. 81, n. 675, p. 82-88, jan. 1992.

PRADO, Luiz Regis; BITENCOURT, C. R. Princípios fundamentais do direito penal. Revista Brasileira de Ciências Criminais, São Paulo, v. 4, n. 15, p. 81-88, jul./set. 1996.

SABBATINI. Renato M.E. Clonar gente, pode ? 1999. Disponível em: <www:http://home.nib.unicamp.br/ sabbatinJornal:http://www.cpopular.com.br>.

SANT'ANNA, Aline Albuquerque. A nova Genética e a tutela penal da integridade física. Rio de Janeiro: Lúmen Júris, 2001.

SARDINHA, J. M. Introdução ao direito penal ecológico. Revista da Ordem dos Advogados, Lisboa, v. 48, p. 447-470, set. 1998.

SILVA, de P. e. Vocabulário jurídico. Atualizado por Geraldo Magela Alves. Vol v. A-Z. Rio de Janeiro: Forense, 1991.

SILVA FRANCO, Alberto. A criminalização das técnicas de engenharia genética. Boletim do Instituto Brasileiro de Ciências Criminais, n.26, 1995.

. Vocabulário jurídico. 10 ed. Rio de Janeiro: Forense, 1987. v. 4.

. Vocabulário jurídico: edição universitária. V. III-IV. Rio de Janeiro: Forense, 1989.

SILVA, J. A. da. Curso de direito constitucional positivo. 16. ed. São Paulo: Malheiros Editores, 1994. 
SILVEIRA, R. M. J. Tutela penal e interesses difusos. Tese (Doutorado em Direito Penal) Universidade de São Paulo, São Paulo.

SIRVINKAS, Luís Paulo. Tutela penal do meio ambiente: breves considerações atinentes à Lei n. 9.605, de 12 de fevereiro de 1998. 2. ed. rev. atual. e ampl. São Paulo: Saraiva, 2002.

TAKEGUMA, Mario Seto. Aspectos fundamentias do tratamento jurídico-penal do parcelamento do solo urbano brasileiro. 2003. 139 f. Dissertação (Mestrado em Direito Penal) - Universidade Estadual de Maringá, Maringá, 2003.

TURESSI, Flávio Eduardo. Breves notas sobre o tratamento da igualdade na legislação penal e processual penal brasileira. Repertório de Jurisprudência IOB. São Paulo, vol. 3. n. 13, jul. 2003.

VARELA, L. B.; LUDWIG. M. C. Da propriedade às propriedades: função social e reconstrução de um direito. In: MARTINS-COSTA, Judith (Org.) A reconstrução do direito privado: reflexos dos princípios, diretrizes e direitos fundamentais constitucionais no direito privado. São Paulo: Revista dos Tribunais, 2002.

WACHBROIT, Robert. Genetic Encores: The Ethics of Human Cloning. 1999. Disponível em: $<$ htt://www.puaf.umd.edu/ipp>.

WAINER, A. H. Legislação ambiental brasileira: subsídios para a história do direito ambiental. Rio de Janeiro: Forense, 1991. 
